treble the normal pressure on the tooth. Although it has ample strength to withstand this augmented pressure as a steady load, if the effect is repeated often enough the metal becomes fatigued, and the tooth may ultimately break off as a result of this fatigue. Thus the fatigue strength should be the criterion employed in design. rather than the more usual considerations of static strength and durability. The experiments further showed that this type of gear can be run under load for many millions of revolutions with scarcely any appreciable wear of the tooth faces, presupposing the best conditions of lubrication. It appears as though the lubricating oil, when functioning efficiently, almost completely holds the steel surfaces apart by a highly tenacious film. Another feature of interest is that even ideally perfect gears must lose some of their running perfection when it is necessary for them to transmit power under heavy loads. This is due to the small elastic bending of the teeth caused by the heavy load, which has the effect of disturbing the perfect uniformity of the motion which the gear would otherwise transmit.

\section{Earthing Radio Sets}

IN the wiring rules issued by the Institution of Electrical Engineers, it is recommended that every radio-receiving set actuated by electric power taken from the public supply mains should be effectively earthed at certain specified points. The obvious way of doing this is to connect these points by conductors with a water pipe. According to the Wireless World for March 23, the Metropolitan Water Board has been investigating to find out whether the leakage currents flowing into their mains are producing appreciable corrosion in the mains or are eating them away at the places where the currents leave them to enter the earth. In the early days of tramway electric traction, where the current when it left the motors was supposed to get back to the generators by the tram rails, it was found that a large proportion of the current left the rails and came back by the earth, the water and gas pipes, and other conductors. In several cases damage was done to the pipes. To obviate this trouble, the Board of Trade insisted that the voltage drop between any two points on the rails should not exceed seven volts, and this has proved satisfactory. If it is found that the leakage currents are damaging the water or gas pipes, we have no doubt that some remedy will soon be invented, as electrical engineers have been making an intensive study of the problem of 'earthing' for several years. It would be very difficult to prove that the damage, if any, is being done by the mainsdriven radio sets, as the currents in the earth are well known to be mainly due to cosmical and atmospheric action and to the leakage or 'vagabond' currents from electric supply stations.

\section{Large Alternators}

IT is gratifying to find from the Metropolitan Vickers Gazette for January that, despite depression in many industrial centres, rapid progress was made during last year in engineering development.
Two turbo-alternators have been supplied to the power station at Clarence Dock, Liverpool, each of which has a power of 71,500 kilovolt-amperes, runs at 1500 revolutions per minute, and generates at 7250 volts. One of the two large 80,000 kilovoltampere machines for the new Battersea Power Station of the London Power Company is now practically completed. This is the largest 1500 r.p.m. machine yet built in Great Britain. The company has also built a 40,000 kva. alternator for the Victoria Falls Power Company, two of 31,250 kva. capacity for Japan, and several for Australia, Mexico, and Calcutta; all of these large machines run at the almost incredible speed of fifty revolutions per second. Three novel and interesting motor-alternator sets have been supplied for operating the Sperry gyroscope equipments on the Italian liner Conte di Savoia. The replacement of human effort by automatic electric control is proceeding very rapidly. The steam pressure in the boilers is maintained at the desired value by automatic regulation of the fans and grates. Substations are sometimes left entirely unattended; the starting, synchronising, and stopping of $14,000 \mathrm{kva}$. alternators being entirely autornatic. The first section of the power station the company is building for Montevideo is now operating. It is interesting to note that the whole of the work from the commence. ment of the excavation of the site to the starting up of the plant was carried through in sixteen months. This performance is excellent considering the distance the bulk of material had to be shipped.

\section{Science Talks by Gramophone}

ScIEnce teaching in schools in the United States is to be enlivened by the employment of gramophones for bringing to the class-rooms the voices of the most eminent men of science. The records are being produced by Science Service, of Washington, D.C. The "Durium" record used consists of a thin layer of a synthetic resin so strong that the sound grooves can be placed very close together, nearly doubling the time of playing. We have received a set of the first seven records, and listened to them with pleasure. The recording has been excellently done, and each speaker gives the kind of talk that would be expected from him were he invited by a teacher to address a class for five minutes. The speakers in this first set are: Prof. Robert A. Millikan, director of the Norman Bridge Physics Laboratory, California Institute, Pasadena, on "The Rise of Physics"; Prof.John C.Merriam, president of the Carnegie Institution, Washington, on "The Record of the Rocks" ; Prof. Edwin G. Conklin, professor of zoology in Princeton University, on "The Mystery of Life"; Prof. Karl T. Compton, president of the Massachusetts Institute of Technology, on "Science and Engineering" ; Prof. L. H. Baekeland, pioneer in industrial chemistry, on "Chemistry and Civilization "; Prof. William H. Welch, professor of the history of medicine in Johns Hopkins University, on "The Tubercle Bacillus" ; and Dr. William M. Mann, director of the National Zoological Park of the Smithsonian Institution, Washington, on "Our Animal Friends". With each record is supplied a card,

No. 3258, VoL. 129] 
bearing on one side a photograph of the speaker and on the other side bibliographical details of his scientific work, together with the complete text of the talk. The set is being offered at an inclusive charge of three dollars, and, at such a low price, may be recommended not only to teachers and students, but also to anyone interested in science in general.

\section{Co-ordination of Scientific Terminology}

Among the scientific questions which the International Institute of Intellectual Co-operation has been asked to examine is the co-ordination of scientific terminology. Various international organisations, including the Commission of Electro-technics and certain scientific unions, have undertaken, each in its respective sphere, the compilation of scientific or technical vocabularies. The different branches of science, however, constantly employ, and very often with a different meaning, terms which are common to all of them. It therefore appeared indispensable that the co-ordination of these terms should be undertaken. For this purpose, a Committee recently met at the International Institute of Intellectual Co-operation. It was composed of Prof. Cabrera (Madrid, chairman); Prof. Cotton (Paris), representing the International Union of Physics; Prof. Willstätter (Munich), Prof. Lowry (Cambridge), delegates of the International Union of Chemistry; Prof. Selys-Longchamps and Dr. Ledoux (Brussels), representing the Intermational Union of Biological Sciences ; and Prof. Lombardi (Rome), delegate of the International Union of Electrotechnics. The Committee invited the International Institute of Intellectual Co-operation to undertake the work of co-ordination in conjunction with the international organisations concerned.

\section{Fourteenth International Physiological Congress}

The Fourteenth International Physiological Congress will be held in Rome on Aug. 28-Sept. 3, as arranged; no change has taken place in the date fixed for it. The president of the Congress is Prof. Bottazzi of Naples, and the International Committee consists of Profs. Pavlov (Russia), Johansson (Sweden), Howell (United States), Frank (Germany), Lapicque (France), and A. V. Hill (Great Britain). The inaugural ceremony will be held in the Giulio Cesare Hall of the Campidoglio. The inaugural lecture will be given by Prof. A. V. Hill, and receptions will be given by the Governor of Rome and the Royal Academy of Italy. Foreign participants in the Congress will enjoy a reduction of fifty per cent for tickets taken, under certain conditions, on the Italian railways. In the near future, those who have already returned their applications for membership will receive further information, and a programme of the inaugural ceremony and other functions.

\section{Announcements}

IT is announced in Science of March 18 that Sir James Jeans has been made an honorary member of the Washington Academy of Sciences, in recognition of his contributions to the dynamical theory of gases, to cosmogony, and to astrophysics.
The William H. Nichols Medal for 1932 of the New York Section of the American Chemical Society was presented on March 1 to Prof. J. B. Conant, chairman of the division of chemistry in Harvard University, in recognition of his work in organic chemistry, particularly in the chemistry of chlorophyll.

Aт the annual general meeting of the Physical Society, held on March 18, the following officers were elected: President, Prof. A. O. Rankine; Secretaries, Dr. Ezer Griffiths (Business), Dr. Allan Ferguson (Papers) ; Foreign Secretary, Prof. O. W. Richardson; Treasurer, Mr. R. S. Whipple; Librarian, Dr. J. H. Brinkworth.

Applications are invited for the following appointments, on or before the dates mentioned :-A male assistant in the Department of Printed Books of the National Library of Wales-The Librarian, National Library of Wales, Aberystwyth (April 12). A registrar of the Wigan and District Mining and Technical College-The Principal, Wigan and District Mining and Technical College, Wigan (April 15). A director of education for the City of Sheffield-The Director of Education, Leopold Street, Sheffield (April 16). A Dickinson research travelling scholar in medicine; a Dickinson research surgery scholar; and a Dickinson research scholar in medicine, each at the Manchester Royal Infirmary-The Secretary to the Trustees, Royal Infirmary, Manchester (April 16). A head of the Commerce Department of the Wigan and District Mining and Technical College - The Principal, Wigan and District Mining and Technical College, Wigan (April 18). A full-time lecturer with degree, and a knowledge of general engineering or mining, at the County Technical Institute, Worksop-The Principal, County Technical Institute, Worksop (April 21). A junior scientific officer in an Admiralty establishment at Portsmouth - The Secretary of the Admiralty (C.E. Branch), Whitehall, S.W.1 (April 23). Probationary assistant naval constructors-The Secretary of the Admiralty (C.E. Branch), Whitehall, S.W.1 (April 30). An assistant in the Department of Forestry of the University College of North Wales-The Registrar, University College of North Wales, Bangor (May 9). A professor of physiology at the London Hospital Medical College-The Academic Registrar, University of London, South Kensington, S.W.7 (May 14). A head of the Mechanical and Electrical Engineering Department of the Harris Institute, Preston-The Principal, Harris Institute, Preston (June 1). An assistant lecturer in civil engineering, building construction and sanitary science at the Battersea Polytechnic--The Principal, Battersea Polytechnic, S.W.11. An assistant master for elementary engineering and metalwork at the Sawston Village CollegeThe Education Secretary, County Hall, Cambridge. A temporary junior assistant with first or second class honours in physics, or equivalent, at the Experimental Station, Porton, near Salisbury-The Chief Superintendent, Chemical Defence Research Department, War Office, 14 Grosvenor Gardens, S.W.1.

No. 3258, VoL. 129] 